\title{
Comparative Analysis of Conventional Anaerobic Digestion and Bio-Electrochemical Systems in Waste Organics Utilization
}

\author{
Yana Mersinkova, Valentin Nenov, Hyusein Yemendzhiev \\ Department of Chemical Technologies, Technical Faculty, Asen Zlatarov University, Burgas, Bulgaria \\ Email: yanna@abv.bg
}

How to cite this paper: Mersinkova, Y., Nenov, V. and Yemendzhiev, H. (2021) Comparative Analysis of Conventional Anaerobic Digestion and Bio-Electrochemical Systems in Waste Organics Utilization. Journal of Agricultural Chemistry and Environment, 10, 428435.

https://doi.org/10.4236/jacen.2021.104028

Received: September 3, 2021

Accepted: November 1, 2021

Published: November 4, 2021

Copyright $\odot 2021$ by author(s) and Scientific Research Publishing Inc. This work is licensed under the Creative Commons Attribution International License (CC BY 4.0).

http://creativecommons.org/licenses/by/4.0/ (c) (i) Open Access

\begin{abstract}
Anaerobic digestion is often used as an approach to deal with high COD waste streams. Compared to the aeration systems it allows better energy management due to the biogas production but also has several limitations including inlet waste streams quality and the additional equipment required for energy harvesting. In recent years, the bio-electrochemical systems (BES) and processes are intensively studied as a method for organic waste utilization, including wastewater. They potentially could bring several benefits to the wastewater treatment, mainly due to avoiding aeration (and aeration cost) and direct energy recovering in the form of electricity. Besides their anaerobic nature, the biological processes in BES are respiration-like contrary to the fermentative degradation typical for conventional anaerobic digestion which eventually will provide better mineralization and higher efficiency in terms of COD and BOD removal in such reactors. This study is a direct comparison between conventional anaerobic digestion and Microbial Fuel Cell (as a typical BES reactor) during utilization of wastewater from industrial production of ethanol by fermentation. COD removal rates and dynamics, energy recovery properties and parameters such as secondary sludge production are investigated in order to characterize the feasibility and technological readiness of BES as a step towards their commercialization.
\end{abstract}

\section{Keywords}

Renewable Energy, Microbial Fuel Cell, Anaerobic Digestion, Wastewater Treatment

\section{Introduction}

Waste and energy management appears as major environmental issues and de- 
velopment of new technologies and general approach on these topics is of great interest for scientific community and society [1]. It is well known that organic matter in wastewater could be a source of energy and if this potential could be utilized it would easily meet the demand of the treatment process itself. In this sense, a recent study estimated that the usual energy value of domestic wastewater could reach $7.4 \mathrm{~kJ}$ per liter (based on the typical COD of $500 \mathrm{mgO}_{2} / \mathrm{L}$ ) and in some cases, when it is mixed with specific industrial waste streams this value could be several times higher [2]. Besides the energy efficiency, the wastewater treatment technics have many technological challenges including the secondary streams generated during the treatment. A huge amount of residual sludge consisting mainly of biomass produces during the utilization of organic waste is probably the main problem to be managed. Anaerobic digestion of biomass is considered one of the most effective and efficient methods of second-generation technology [3]. The sludge streams from domestic and industrial wastewater treatment are stabilized in anaerobic condition in a process which involves digestion, fermentation, gasification, incineration, and pyrolysis [4] [5] [6]. During this treatment the organic matter in the wastes is reduced and some energy is recovered in the form of biogas. The process is conducted by the catalytically activity of several groups of microorganism which are responsible for the transformation of the complex organics via hydrolysis, acidogenesis, acetogenesis and methanogenesis [7]. The anaerobic digestion works effectively in both mesophilic $\left(30^{\circ} \mathrm{C}-35^{\circ} \mathrm{C}\right)$ and thermophilic $\left(50^{\circ} \mathrm{C}-60^{\circ} \mathrm{C}\right)$ conditions, and for this reason temperature control is often needed [8].

Biogas consists mainly of methane and carbon dioxide with small amounts of nitrogen, hydrogen and H2S [9] [10]. Most of the biogas is produced in the middle of digestion after the bacterial population has increased and decreased due to the fact that the substrate begins to deplete [11]. The gas is normally stored on top of the digester in an inflatable gas bubble or extracted and stored next to the facility in a gas holder. The methane in biogas can be burned to produce both heat and electricity.

The anaerobic digestion cannot break down compounds, such as lignin which need to be utilized in anaerobic conditions and they remain in the residuals after the process. anaerobically. These compounds could inhibit the growth of plants when if $\mathrm{AD}$ excess sludge is directly used as a fertilizer, so addition treatment such as composting and aerobic biodegradation is needed [12] [13].

As an alternative, bio-electrochemical processes offer many of the benefits of the anaerobic digestion but avoiding some of the above mentioned drawbacks Microbial Fuel Cells (MFC) are example of bio-electrochemical type of reactors which are intensively studied in the recent years. They combine biological and electrochemical processes to generate electricity, hydrogen or other useful chemicals form organic substrates, including waste organics. MFCs have attracted interest following the recent trends of developing sustainable methods and products. They offer simultaneous wastewater treatment and direct electrical energy harvesting which could significantly improve the water management environ- 
mental footprint in general [14]. The organic substrates in MFC reactors are biologically oxidized in the anode compartment under anaerobic conditions, where the oxygen as a terminal electron acceptor is replaced by the anode itself. The microorganisms driving this process are able to transfer directly the electrons obtained from the decomposition of the organic molecules to the anode. These electrons flow through an external electric circuit to the cathode where they are consumed in different cathodic reactions (usually an oxidant agent reduction). Due to the presence of communities in wastewater, they serve as a source of bacteria for the formation of electrochemically active biofilm on the anode surface [15] [16]. From the biochemical point of view, there is fundamental difference between the conventional anaerobic digestion and bio-electrochemical processes even though both processes are anaerobic. Anaerobic digestion is predominantly fermentative transformation of the substrates without involvement of any complex electron transport mechanisms for ATP synthesis. On the contrary, in the microbial fuel cell, a respiratory type of metabolism is implemented with all the typical energy benefits for the bacterial cell.

Anaerobic cellular respiration is similar to aerobic cellular respiration in that electrons extracted from a fuel molecule (organic substrate or the pollutants in the treated wastewater) are passed through an electron transport system, driving ATP synthesis. The only difference between the two processes is the terminal electron acceptor due to the absence of oxygen attributed to the anaerobic conditions.

This study aims to directly compare conventional anaerobic digestion and Microbial Fuel Cell (as a typical BES reactor) during utilization of wastewater from industrial production of ethanol by fermentation. COD removal rates and dynamics, energy recovery properties and parameters such as secondary sludge production are investigated in order to characterize the feasibility and technological readiness of BES as a step towards their commercialization.

\section{Experimental}

\subsection{Wastewater Characteristics}

The waste stream treated in the studied reactors contains the industrial wastewater flows collected form a different technological processes during the preparation and processing of the raw materials for the fermentation, alcoholic fermentation itself and the distillation of the final product. The main parameters are as follow: Conductivity-1480 $\mu \mathrm{S} / \mathrm{cm}$; $\mathrm{pH}-6.8$; COD $-1980 \mathrm{mgO}_{2} / \mathrm{dm}^{3}$; Volatile fatty acids $-460 \mathrm{mg} / \mathrm{dm}^{3}$; Total Nitrogen $-29.2 \mathrm{mg} / \mathrm{dm}^{3}$; Total Phosphorus- $-11 \mathrm{mg} / \mathrm{dm}^{3}$.

\subsection{Anaerobic Digester Operation Parameters}

The anaerobic digester which was a subject of this study is a key wastewater treatment reactor in the ethanol and wine production facility near Burgas, Bulgaria. The complete scheme of treatment includes Pumping station, grids, pri- 
mary clarifier, mixing and equalization tank, the anaerobic reactor itself and final sedimentation tank. Mixed culture presented in the anaerobic reactor includes high number of acetogenic and methanogenic bacteria. Biogas produced during the digestion is collected in the upper part of the reactor and then collected by the dedicated gas line. During the process, the anaerobic digester is maintained in mesophilic conditions with temperature between $30^{\circ} \mathrm{C}-35^{\circ} \mathrm{C}$ and pH 6.8 - 7 .

\subsection{MFC Configuration and Operation}

The prototype MFC used in this study was assembled as a cylindrical plastic reactor consists of two chambers separated by Nafion ${ }^{\circledR} 424$ perfluorinted proton exchange membrane. The cell segments were equipped with the respective sampling and gas/liquid transport ports. The electrodes were $30 \mathrm{~mm}$ in diameter made of carbon cloth with stainless steel current collectors. They were connected with external electric circuit loaded with $1000 \mathrm{Ohms}$ resistor. The volumes of cathode and anode chambers were $45 \mathrm{dm}^{3}$ (Figure 1). The anode compartment is fed by wastewater and inoculated with biomass form the anaerobic digester $(2 \% \mathrm{w} / \mathrm{w}) .2 \%$ solution potassium ferricyanide used as catholyte and terminal electron acceptor. The process is conducted in ambient temperature of $18^{\circ} \mathrm{C}$ $20^{\circ} \mathrm{C}$.

\subsection{Analytical Methods}

The Chemical Oxygen Demand (COD) was measured using Lange cuvette tests (LCK 314) and HACH DR 3900 spectrophotometer.

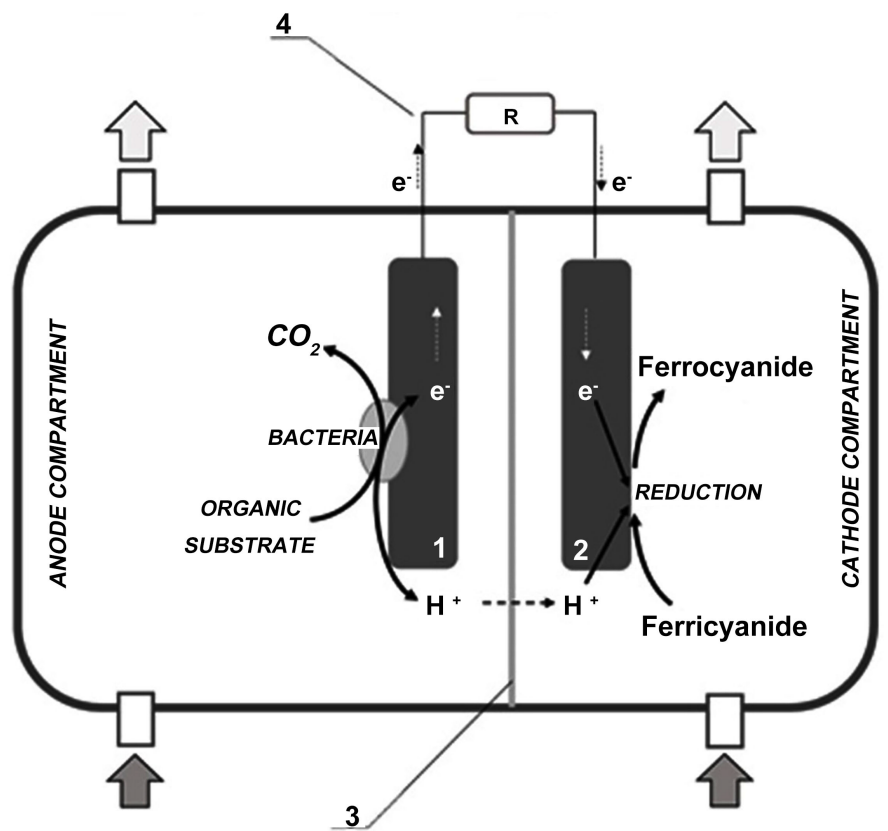

Figure 1. Experimental design and construction of the microbial fuel cell used in the experiments: 1-anode; 2-cathode; 3-proton exchange membrane; 4 -external electric circuit. 
The biomass growth was measured by KERN DAB100-3 Moisture and dry weight and expressed as a concentration of dry biomass.

The yield and the specific yield of residual sludge were calculated by the difference in the amount of the final and initial biomass measured and then the values were related to the COD removed during the time of process.

All analyses and measurements were performed in three replicates and the mean values are presented in the corresponding graphs and tables.

\section{Results and Discussion}

For the purposes of this study, the dynamics of COD removal in industrial anaerobic digester and Microbiological Fuel Cell constructed as a lab-prototype were compared during utilization of real waste stream from ethanol production and distillation. The data obtained and direct comparison of the main parameters of both processes is presented in Figure 2 and Table 1. A high efficiency (above 95\%) in terms of COD removal was observed in both cases. However, it was found that the anaerobic digestion requires significantly shorter treatment time to achieve this efficiency rate (about 120 hours vs. 380 hours). The COD removal rates are comparable since the values are of same order, but again the advantage of anaerobic digestion is obvious. Given that anaerobic degradation is a process that has been very well integrated in the industry for years it has reached high advanced technical and technological state of development in terms of equipment design and process control and optimization, so this results are not unexpected. However, in certain stages of the biodegradation process in the IGC the maximum (instantaneous) COD removal rates observed in MFC reactor are almost two times higher, which clearly demonstrate the potential of bio-electrochemical methods. Probably this new technology hides significant opportunities that can be developed by optimizing both the technique (design) and the process parameters. Another positive characteristic of MFCs is the almost twice lower yield of excess sludge during the water treatment process, which can be a great technological advantage given the fact that residual sludge in a secondary waste flow which have to be managed and processed. In addition, MFCs offer a potential opportunity to recover energy from waste directly in the form of electricity, avoiding the additional technological stages such as burning biogas to harvest energy. Furthermore, even if both processes were carried out solely for the purpose of waste streams stabilizing or treatment (without targeted energy recovery), the elimination of mechanization would significantly reduce the carbon footprint of wastewater treatment activities due to the fact that methane is a much stronger greenhouse gas than carbon dioxide (which is the only end product of the biological degradation of organic matter in MFCs). Of course, another factor in this sense is the temperature regime difference between anaerobic digestion which often needs heating and temperature control and bioelectrochemical processes characterized by significantly lower (close to the ambient) temperature requirements. 
Table 1. Comparison of the performans of anaerobic digestion (AD) with that of microbial fuel cells (MFC).

\begin{tabular}{lll}
\hline PARAMETER & Anaerobic digestion (AD) & Microbial fuel cell (MFC) \\
\hline HYDRAULIC RETENTION TIME & $120 \mathrm{~h}$ & $384 \mathrm{~h}$ \\
TEMPERATURE REGIMES & $\begin{array}{l}30^{\circ} \mathrm{C}-35^{\circ} \mathrm{C} \text { (requires heating and temperature } \\
\text { control) }\end{array}$ & $\begin{array}{l}18^{\circ} \mathrm{C}-20^{\circ} \mathrm{C} \text { (doesn't require heating } \\
\text { and temperature control) }\end{array}$ \\
COD REMOVAL EFFICIENCY & $95.7 \%$ & $97 \%$ \\
AVERAGE COD REMOVAL RATE & $376.2 \mathrm{mg} / \mathrm{dm}^{3} / \mathrm{day}$ & $118.3 \mathrm{mg} / \mathrm{dm}^{3} / \mathrm{d}$ \\
MAXIMUM COD REMOVAL RATE & $380 \mathrm{mg} / \mathrm{dm}^{3} /$ day & $722 \mathrm{mg} / \mathrm{dm}^{3} / \mathrm{day}^{\prime}$ \\
BIOMASS GROWTH (EXCESS & & \\
ACTIVATED SLUDGE-DRY WEIGHT & $0.159 \mathrm{~g} / \mathrm{g} \mathrm{COD}$ & $0.09 \mathrm{~g} / \mathrm{g} \mathrm{COD}$ \\
PER GRAM COD) & & \\
ENERGY RECOVERY & Biogas (heat and electricity after cogeneration) & Direct electricity generation
\end{tabular}

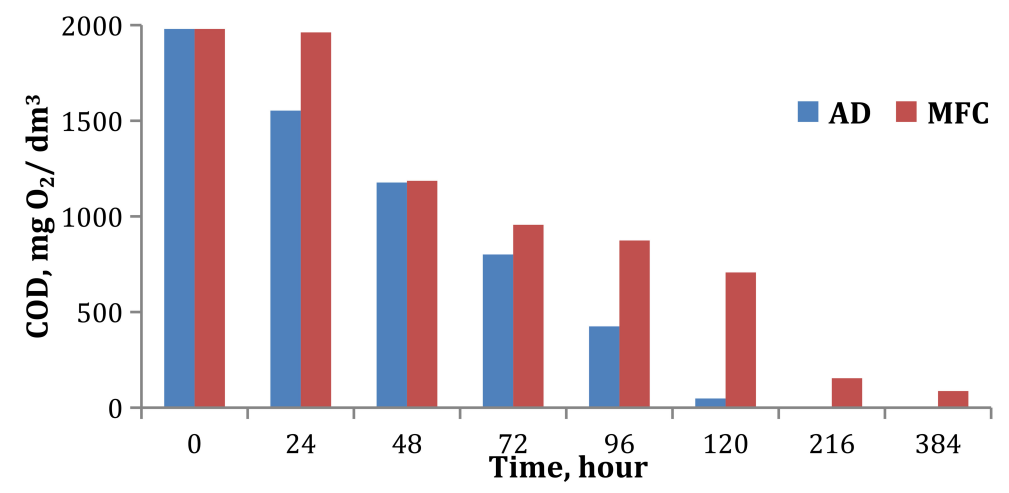

Figure 2. COD removal dynamics (Blue-Anaerobic digestion; Red-Microbial Fuel Cell).

\section{Conclusion}

Based on the data obtained MFC technology demonstrated a great potential to be used as an alternative approach for utilization of waste streams with high organic load. Although, the anaerobic digestion and the rectors used are well developed and improve over the years of industrial application and at this stage they are available industrial technology contrary to bio-electrochemical processes and Microbial Fuel Cells which are still far from commercialization. Anyway, these new reactors have a promising future and advantages which are still to be uncovered. However, many obstacles cloud occur in their real life implementation, including scaling problems and hidden long term exploitation costs.

\section{Acknowledgements}

This work was supported by the Bulgarian Ministry of Education and Science under the following projects:

- National Scientific Programme "Young Scientists and Postdoctorates"

- National Research Programme E+: Low Carbon Energy for Transport and Households" DCM577/17.08.2018 


\section{Conflicts of Interest}

The authors declare no conflicts of interest regarding the publication of this paper.

\section{References}

[1] Hussey, K. and Pittock, J. (2012) The Energy-Water Nexus: Managing the Links between Energy and Water for a Sustainable Future. Ecology and Society, 17, 31-39. https://doi.org/10.5751/ES-04641-170131

[2] Heidrich, E.S., Curtis, T.P. and Dolfing, J. (2001) Determination of the Internal Chemical Energy of Wastewater. Environmental Science \& Technology, 45, 827-832. https://doi.org/10.1021/es103058w

[3] Lee, S.Y., Sankaran, R., Chew, K.W., Tan, C.H., Krishnamoorthy, R., Chu, D.-T. and Shown, P.-L. (2019) Waste to Bioenergy: A Review on the Recent Conversion Technologies. BMC Energy, 1, Article No. 4.

https://doi.org/10.1186/s42500-019-0004-7

[4] Appels, L., Baeyens, J., Degrève, J. and Dewil, R. (2008) Principles and Potential of the Anaerobic Digestion of Waste-Activated Sludge. Progress in Energy and Combustion Science, 34, 755-781. https://doi.org/10.1016/j.pecs.2008.06.002

[5] Fytili, D. and Zabaniotou, A. (2008) Utilization of Sewage Sludge in EU Application of Old and New Methods-A Review. Renewable and Sustainable Energy Reviews, 12, 116-140. https://doi.org/10.1016/j.rser.2006.05.014

[6] Luque, R., Menéndez, J.A., Arenillas, A. and Cot, J. (2012) Microwave-Assisted Pyrolysis of Biomass Feedstocks: The Way Forward? Energy \& Environmental Science, 5, 5481-5488. https://doi.org/10.1039/C1EE02450G

[7] Horváth, I.S., Tabatabaei, M., Karimi, K. and Kumar, R. (2016) Recent Updates on Biogas Production-A Review. Biofuels Research Journal, 10, 394-402.

https://doi.org/10.18331/BRJ2016.3.2.4

[8] Kumar, V., Bhatia, A., Kubota, K. and Rajpal, A. (2021) Environmental Technology \& Innovation Microbial Community Dynamics in Anaerobic Digesters Treating Organic Fraction of Municipal Solid Waste. Environmental Technology \& Innovation, 21, Article ID: 101303. https://doi.org/10.1016/j.eti.2020.101303

[9] Roubík, H., Mazancová, J., Banout, J. and Verner, V. (2016) Addressing Problems at Small-Scale Biogas Plants: A Case Study from Central Vietnam. Journal of Cleaner Production, 112, 2784-2792. https://doi.org/10.1016/j.jclepro.2015.09.114

[10] Anukam, A., Mohammadi, A., Naqvi, M. AND Granström, K. (2019) A Review of the Chemistry of Anaerobic Digestion: Methods of Accelerating and Optimizing Process Efficiency. Processes, 7, 504-523. https://doi.org/10.3390/pr7080504

[11] Tyagi, V.K., Bhatia, K., Kubota, K., Rajpal, A., Ahmed, B., Khan, A.A., Kazmi, A.A. and Kumar, M. (2021) Microbial Community Dynamics in Anaerobic Digesters Treating Organic Fraction of Municipal Solid Waste. Environmental Technology \& Innovation, 21, 101303. https://doi.org/10.1016/j.eti.2020.101303

[12] Dosta, J., Galí, A., Macé, S. and Mata-Álvarez, J. (2007) Modelling a Sequencing Batch Reactor to Treat the Supernatant from Anaerobic Digestion of the Organic Fraction of Municipal Solid Waste. Journal of Chemical Technology \& Biotechnology, 82, 158-164. https://doi.org/10.1002/jctb.1645

[13] Talbot, J.M. and Treseder, K.K. (2012) Interactions among Lignin, Cellulose, and Nitrogen Drive Litter Chemistry-Decay Relationships. Ecology, 93, 345-354. https://doi.org/10.1890/11-0843.1 
[14] Venkata, M.S. (2012) Harnessing Bioelectricity through Microbial Fuel Cell from Wastewater. Renew Energy, 5, 24-28.

[15] Sun, G.T., Thygesen, A. and Meyer, A.S. (2015) Acetate Is a Superior Substrate for Microbial Fuel Cell Initiation Preceding Bioethanol Effluent Utilization. Applied Microbiology and Biotechnology, 99, 4905-4915.

https://doi.org/10.1007/s00253-015-6513-5

https://link.springer.com/article/10.1007/s00253-015-6513-5

[16] Min, B. and Logan, B.E. (2004) Continuous Electricity Generation from Domestic Wastewater and Organic Substrates in a Flat Plate Microbial Fuel Cell. Environmental Science \& Technology, 38, 5809-5814. https://doi.org/10.1021/es0491026 